\title{
Pharmacological Countermeasures to Spaceflight-Induced Alterations of the Immune System
}

\author{
Nathan Guéguinou, Matthieu Bascove, \\ and Jean-Pol Frippiat
}

\subsection{Introduction}

Opportunities for microbes to establish infections are enhanced under spaceflight conditions because space travel stimulates their growth (Chap. 15) and has a negative impact on immune functions. Indeed, it has been shown that spaceflight affects lymphoid organs (Gridley et al. 2003; Baqai et al. 2009) and induces variations in peripheral blood leukocyte subsets (Chap. 9). Neutrophil, monocyte, and NK cell functions are affected by spaceflight (Chaps. 10-12). The activation of T lymphocytes is also severely depressed under low gravity conditions (Cogoli et al. 1984) because interleukin-2 (IL-2) and IL-2receptor gene expression are modified, the delivery of the costimulatory signal to activate the B7/CD28 pathway and the protein kinase A (PKA) signaling pathway, which is a key early regulator in $\mathrm{T}$ cell activation, are hindered. Furthermore, a TH2 cytokine shift is associated with spaceflight. If this $\mathrm{TH} 2$ shift persists during long missions, it could represent a significant clinical risk for TH2-related autoimmune diseases, allergies, hypersensitivities, and disease susceptibility related to diminished cell-mediated immunity. Studies on plasma antibody levels did not reveal significant changes after short spaceflights (Rykova et al. 2008), but contradictory results were reported after long missions. Indeed, several studies (Konstantinova et al. 1993; Bascove et al. 2008, 2009; Guéguinou et al. 2009, 2010) reported increased levels of immunoglobulin while Rykova et al. (2008) reported normal amounts of antibodies after prolonged space missions. Lastly, a differential sensitivity of cellular and humoral immunity to spaceflight conditions seems to exist because it was shown that the cellular, but not the humoral, systems are affected by short periods of flight.

N. Guéguinou • M. Bascove • J.-P. Frippiat $(\bowtie)$

Faculty of Medicine, Nancy-University, Henri Poincaré University, Development and Immunogenetics, Vandœuvre-lès-Nancy, France e-mail: jean-pol.frippiat@ scbiol.uhp-nancy.fr 
Taken together, these data demonstrate that spaceflight-induced modifications of the immune system could have an immediate impact on mission objectives. The development of efficient countermeasures to combat the deleterious effects of spaceflight on the immune system is therefore an area that should be considered more thoroughly before we undertake prolonged space voyages. Furthermore, the observations presented above are also found in the elderly (Cancro et al. 2009) and people subjected to chronic or acute stress (see Chap. 4). Indeed, the age-associated decline in immune function, which is known as immunosenescence, is characterized by a large dysfunction in innate and adaptive immune system responses (for review see Weiskopf et al. 2009). Chronic stress reduces B and T lymphocyte responses and lowers antibody production (Glaser et al. 2000). Acute stress induces the reactivation of latent viruses, decreases NK cell activity, increases interleukin-6 (IL-6) secretion, and increases neutrophil numbers in peripheral blood (Glaser and Kiecolt-Glaser 2005). Finding countermeasures to spaceflight-associated immune alterations are therefore also of interest to counter immunosenescence and the effects of stress-inducing situations on Earth.

\subsection{Effect of Combined Antioxidant Treatment}

Increased oxidative stress, which is harmful for cells and can induce many disorders, has been observed after radiation exposure and is associated with spaceflight (Stein and Leskiw 2000; Wan et al. 2005). Indeed, lipopolysaccharide (LPS)-activated splenocytes from mice that flew on the space shuttle mission STS-118 produced more IL-6 and interleukin-10 (IL-10) and less tumor necrosis factor (TNF)- $\alpha$ than control mice (Baqai et al. 2009). The same study showed that many of the genes responsible for scavenging reactive oxygen species (ROS) were upregulated after the flight, suggesting that cells attempted to scavenge ROS produced during spaceflight. An increase in the superoxide response by murine polymorphonuclear neutrophils was also reported even after short periods of microgravity (Fleming et al. 1991). Furthermore, it was shown that the urinary concentration of 8-hydroxy-2'deoxyguanosine, a marker of oxidative damage to DNA, was higher and that red blood cell superoxide dismutase, an antioxidant enzyme that functions as a superoxide radical scavenger, was lower in astronauts after long-duration spaceflight (Smith and Zwart 2008). Consequently, research was undertaken to determine if antioxidants could protect organisms from radiation-induced oxidative stress. Two studies showed that a mixture of L-selenomethionine (SeM), vitamin C, vitamin E succinate, alpha-lipoic acid, and $\mathrm{N}$-acetyl cysteine improved the survival of mice after exposure to protons or to a potentially lethal dose of X-rays (Wambi et al. 2008, 2009) (Table 30.1). Pretreatment of mice with this mixture of antioxidants resulted in significantly higher total white blood cell and neutrophil counts in the peripheral blood and increased bone marrow cell counts after irradiation. Moreover, antioxidants increased Bcl-2 (B cell lymphoma-2, proteins regulating anti-apoptotic mechanisms) and decreased $\mathrm{Bax}$ (Bcl-associated $\mathrm{X}$ protein promoting apoptosis), caspase 9 , and TGF (transforming growth factor)- $\beta 1 \mathrm{mRNA}$ expression in the bone marrow after X-ray irradiation (Wambi et al. 2008). In mice or rats exposed to high-energy 
particles radiation, D- or L-SeM or a combination of selected antioxidant agents, which included SeM, could also prevent the decrease in total antioxidants by regulating the expression of genes involved in the repair of radiation-induced DNA damage (Kennedy et al. 2004, 2007). These data indicate that antioxidants, alone or in combination, are promising countermeasures for protection against adverse biological effects from space radiation.

\subsection{Nucleotides}

Nucleotides are beneficial for health because they positively influence lipid metabolism, immunity, and tissue growth, development, and repair (Gil 2002). Rapidly proliferating tissues, such as those of the immune system, are not able to fulfill the

Table 30.1 Effect of countermeasures on immune parameters

\begin{tabular}{|c|c|c|c|}
\hline Countermeasure & Experiment performed & Results & References \\
\hline \multirow[t]{2}{*}{ Antioxidants } & $\begin{array}{l}\text { Irradiated } \\
\text { mice }+ \text { antioxidants }\end{array}$ & $\begin{array}{l}\text { - Antioxidants prevented the } \\
\text { decrease of the antioxidant status } \\
\text { of animals exposed to protons or } \\
\text { high-energy particles }\end{array}$ & $\begin{array}{l}\text { Kennedy } \\
\text { et al. } 2007\end{array}$ \\
\hline & $\begin{array}{l}\text { Irradiated mice } \\
\text { (X-rays) + antioxidants }\end{array}$ & $\begin{aligned}- & \uparrow \text { survival } \\
- & \uparrow \text { white blood cells and } \\
& \text { neutrophils in blood } \\
- & \uparrow \text { bone marrow cell counts } \\
- & \uparrow \text { Bcl- } 2 \text { mRNA in bone marrow } \\
- & \downarrow \text { Bax, caspase } 9 \text { \& TGF- } \beta 1 \\
& \text { mRNA in bone marrow }\end{aligned}$ & $\begin{array}{l}\text { Wambi et al. } \\
2008\end{array}$ \\
\hline \multirow[t]{4}{*}{ Nucleotides } & $\begin{array}{l}\text { In vitro } \\
\text { Mouse splenocytes } \\
\text { cultured under simulated } \\
\text { microgravity conditions } \\
\text { and stimulated with } \\
\text { PHA + nucleotides }\end{array}$ & $\begin{array}{l}\text { - Nucleoside-nucleotide mixture } \\
\text { and uridine restored splenocyte } \\
\text { proliferation } \\
-\uparrow \text { IL- } 1 \beta, \text { IL- } 2 \& \text { IFN- } \gamma \text { with the } \\
\text { nucleoside-nucleotide mixture }\end{array}$ & $\begin{array}{l}\text { Hales et al. } \\
2002\end{array}$ \\
\hline & $\begin{array}{l}\text { In vivo } \\
\text { Hindlimb-unloaded } \\
\text { mice + nucleotides }\end{array}$ & $\begin{array}{l}\text { - RNA and uracil restored } \\
\text { popliteal lymph node prolifera- } \\
\text { tion, PHA-induced proliferation } \\
\text { of splenocytes, IL- } 2 \& \text { IFN- } \gamma \\
\text { production }\end{array}$ & $\begin{array}{l}\text { Kulkarni } \\
\text { et al. } 2002 \text {, } \\
2005\end{array}$ \\
\hline & $\begin{array}{l}\text { In vitro } \\
\text { Mouse splenocytes cultured } \\
\text { under simulated micrograv- } \\
\text { ity conditions and } \\
\text { stimulated with } \\
\text { PHA + nucleotides }\end{array}$ & $\begin{array}{l}\text { - PHA-induced proliferation of } \\
\text { splenocytes restored by uridine } \\
\text { and nucleoside-nucleotide } \\
\text { mixture }\end{array}$ & $\begin{array}{l}\text { Kulkarni } \\
\text { et al. } 2002 \text {, } \\
2005\end{array}$ \\
\hline & $\begin{array}{l}\text { In vivo } \\
\text { Hindlimb-unloaded } \\
\text { mice + nucleotides }\end{array}$ & $\begin{array}{l}-\uparrow \text { proliferation } \\
-\uparrow \text { IL-2 \& IFN- } \gamma \\
-\downarrow \text { corticosterone plasma level }\end{array}$ & $\begin{array}{l}\text { Yamauchi } \\
\text { et al. } 2002\end{array}$ \\
\hline
\end{tabular}


Table 30.1 (continued)

\begin{tabular}{|c|c|c|c|}
\hline Countermeasure & Experiment performed & Results & References \\
\hline \multirow[t]{3}{*}{$\mathrm{AHCC}$} & $\begin{array}{l}\text { Hindlimb-unloaded mice } \\
\text { infected with } K \text {. } \\
\text { pneumoniae }+ \text { AHCC }\end{array}$ & $\begin{array}{l}-\downarrow \text { mortality } \\
-\uparrow \text { time to death and ability to } \\
\text { clear bacteria } \\
-\uparrow \text { anti-K. pneumoniae } \text { IgG levels }\end{array}$ & $\begin{array}{l}\text { Aviles et al. } \\
2003\end{array}$ \\
\hline & $\begin{array}{l}\text { Normally housed } \\
\text { mice + AHCC }\end{array}$ & $\begin{array}{l}-\uparrow \text { spleen cell proliferation } \\
\text { induced by Con-A or LPS } \\
-\uparrow \text { IL- } 2 \text { \& IFN- } \gamma \text { after Con-A } \\
\text { stimulation } \\
-\uparrow \text { IL- } 4, \text { IL- } 6 \text { \& IL-10 after LPS } \\
\text { stimulation } \\
-\uparrow \text { nitric oxide production in } \\
\text { peritoneal cells }\end{array}$ & $\begin{array}{l}\text { Aviles et al. } \\
2004\end{array}$ \\
\hline & $\begin{array}{l}\text { Hindlimb-unloaded } \\
\text { mice + AHCC }\end{array}$ & $\begin{array}{l}\text { - No effect on splenocyte } \\
\text { proliferation induced by Con-A } \\
\text { or LPS } \\
-\uparrow \text { IL-2 \& IFN- } \gamma \text { after Con-A } \\
\text { stimulation } \\
-\uparrow \text { nitric oxide production in } \\
\text { peritoneal cells } \\
\text { - Restored peritoneal cell function }\end{array}$ & $\begin{array}{l}\text { Aviles et al. } \\
2004\end{array}$ \\
\hline \multirow[t]{4}{*}{ DHEA } & $\begin{array}{l}\text { In vitro } \\
\text { KLH-primed mouse } \\
\text { splenocytes stimulated } \\
\text { with KLH+DHEA }\end{array}$ & $\begin{array}{l}\text { TH2 favored } \\
-\uparrow \text { IL-4 } \\
-\downarrow \text { IFN- } \gamma\end{array}$ & $\begin{array}{l}\text { Du et al. } \\
2001\end{array}$ \\
\hline & $\begin{array}{l}\text { In vitro } \\
\text { Mouse splenocytes } \\
\text { stimulated with Con-A } \\
\text { and LPS + DHEA }\end{array}$ & $\begin{array}{l}-\downarrow \text { IL-1, IL-2 \& IFN- } \gamma \\
-\uparrow \text { IL-10 } \\
- \text { IL-4, IL-6 \& TNF- } \alpha \text { not affected }\end{array}$ & $\begin{array}{l}\text { Powel and } \\
\text { Sonnenfeld } \\
2006\end{array}$ \\
\hline & $\begin{array}{l}\text { In vivo } \\
\text { Retrovirus infected } \\
\text { mice+DHEA }\end{array}$ & $\begin{array}{l}\text { TH1 favored } \\
-\uparrow \text { IL-2 \& IFN- } \gamma \\
-\downarrow \text { IL-6 \& TNF- } \alpha\end{array}$ & $\begin{array}{l}\text { Araghi- } \\
\text { Niknam } \\
\text { et al. } 1997\end{array}$ \\
\hline & $\begin{array}{l}\text { In vivo } \\
\text { Old female mice }+ \text { DHEA }\end{array}$ & $\begin{array}{l}-\uparrow \text { IL-2 \& IFN- } \gamma \\
-\downarrow \text { IL-6 \& IL-10 }\end{array}$ & $\begin{array}{l}\text { Inserra et al. } \\
1998\end{array}$ \\
\hline
\end{tabular}

Arrows indicate up and down modulations

needs of cell nucleotides exclusively by de novo synthesis and consequently use the salvage pathway that recovers nucleotides from the blood and diet. Nucleotides modulate the immune system (Nagafuchi et al. 1997; Holen et al. 2006). They influence lymphocyte maturation, activation, and proliferation. Likewise, they affect lymphocyte subset populations in the blood and are involved in enhancing macrophage phagocytosis and delayed hypersensitivity as well as allograft and tumor responses. In addition, they contribute to the immunoglobulin response (Navarro et al. 1996; Nagafuchi et al. 1997; Maldonado et al. 2001), which has a positive effect on clearing infection. The molecular mechanisms by which 
nucleotides modulate the immune system are largely unknown. Nucleotides may influence protein biosynthesis as well as signal membrane transduction mediated by the interaction of exogenous nucleosides and their receptors. They may also contribute to modulating the expression of a number of genes, including those involved in the immune system.

Because nutrient absorption and metabolism appear to be altered under spaceflight conditions (see Chap. 29), several studies have analyzed the effects of an exogenous source of nucleotides on immune function using ground-based models of microgravity. Hales et al. (2002) and Kulkarni et al. (2002, 2005) have shown that the decreased splenocyte proliferation in response to phytohemagglutinin (PHA) under simulated microgravity can be restored by a nucleoside-nucleotide mixture and uridine but not by inosine. This observation indicates that pyrimidines are more effective for immunoprotection of the hosts (Table 30.1). In vitro studies also revealed that cultured splenocytes secreted more IL-1 $\beta$, IL-2, and interferon (INF)- $\gamma$ in the presence of a nucleoside-nucleotide mixture. In addition, Kulkarni et al. (2002, 2005) performed in vivo studies that demonstrated that popliteal lymph node proliferation, PHA-induced splenocyte proliferation, and IL-2 and IFN- $\gamma$ production, which are significantly suppressed in hindlimb-unloaded mice (a ground-based model of choice for simulating spaceflight conditions on Earth (Morey-Holton and Globus 2002)), are restored by RNA and uracil. Similarly, Yamauchi et al. (2002) showed that in hindlimb-unloaded mice, nucleotides significantly increased in vivo lymph node proliferation and ex vivo lymphoproliferation response to alloantigen and mitogens, respectively, and IL-2 and IFN- $\gamma$ production. Moreover, a lower plasma corticosterone level was observed in hindlimb-unloaded mice with RNA and uracil-supplemented diet. Thus, nucleotides and especially uracil/uridine possess immunoprotective effects. These molecules are therefore potential countermeasures for the observed immune dysfunction associated with space travel.

\subsection{AHCC}

Another interesting compound is the active hexose-correlated compound (AHCC). AHCC is an extract prepared from cocultured mycelia of several species of Basidiomycete mushrooms that contains $40 \%$ of polysaccharides ( $\beta$-glucan and acetylated $\alpha$-glucan which are known to have immune-stimulating effects), amino acids, and minerals. Despite the fact that it is not yet an approved drug, AHCC is the second most popular complementary and alternative medicine used by cancer patients in Japan. It is available to the general public without a prescription. Its legal status is that of a functional food. AHCC may help in the treatment of cancer. Indeed, a cohort study showed a significantly longer no recurrence period and an increased overall survival rate in 113 postoperative liver cancer patients taking AHCC (Matsui et al. 2002). Another study showed that AHCC significantly enhanced cisplatin-induced antitumor effect (Hirose et al. 2007). Several studies have shown that this product has also a positive effect on human and rodent immune systems, including the enhancement of host resistance to influenza and West Nile viruses, the prevention of 
thymic apoptosis induced by dexamethasone, the increase of natural killer cell activity, and the induction of IL-12 production (Burikhanov et al. 2000; Matsui et al. 2002; Yagita et al. 2002; Nogusa et al. 2009; Wang et al. 2009). Consequently, it was tested on hindlimb-unloaded mice that present decreased resistance to bacterial infections (Klebsiella pneumoniae and Pseudomonas aeruginosa) (Belay et al. 2002; Aviles et al. 2003). Indeed, hindlimb unloaded mice showed significantly increased mortality and reduced mean time to death, increased levels of corticosterone, reduced ability to clear bacteria from their organs, and delayed production of anti-P. aeruginosa IgG antibodies, by comparison with controls. Aviles et al. (2003) showed that the administration of AHCC for one week before suspension and throughout the 10-day suspension period yielded significant beneficial effects for hindlimb-unloaded mice infected with $K$. pneumoniae, including decreased mortality, increased time to death, and increased ability to clear bacteria (Table 30.1). Furthermore, mice receiving AHCC independent of the type of treatment (hindlimb-unloaded or normally caged) had higher anti-K. pneumoniae IgG antibody levels. The same team later demonstrated that AHCC significantly enhanced the function of the immune system in normally housed mice but only enhanced the TH1 response in mice under hindlimb-unloading conditions (Aviles et al. 2004) (Table 30.1). Interestingly, TH1 cytokine production has been shown to be depressed after short- and long-duration missions on the International Space Station (Crucian et al. 2008). Indeed, both groups of astronauts had a low IFN- $\gamma$ to IL-10 secretion ratio on the day of landing after activation of peripheral blood T cells with anti-CD3 and anti-CD28 antibodies. This observation was confirmed by another study performed on PHA-stimulated splenocytes from mice flown on STS-108, which revealed that both IL-2 and IFN- $\gamma$ were significantly lower after the flight (Gridley et al. 2003) indicating that a shift toward the TH2 subset is associated with spaceflight. AHCC also restored peritoneal cell functions that are suppressed by hindlimb-unloading and increased nitric oxide production in peritoneal cells isolated from hindlimb-unloaded mice. Other studies showed that AHCC enhanced resistance to infection. In a mouse model of surgical wound infection, mice receiving $\mathrm{AHCC}$ were better able to clear bacteria from their systems than control animals (Aviles et al. 2006). AHCC also increased immune function that resulted in a lower bacterial load in a murine model of intramuscular infection (Aviles et al. 2008). In conclusion, AHCC appears to be an efficient immunoenhancer that restores innate immunity, which is greatly affected by hindlimb-unloading, and consequently represents another countermeasure with great potential that warrants further investigation.

\subsection{DHEA}

Dehydroepiandrosterone (DHEA) is one of the major circulating adrenal cortical hormones in humans and many other warm-blooded animals. This hormone is secreted by the adrenal cortex in response to stress (Kroboth et al. 1999). In the plasma, DHEA is predominantly present as DHEA-S that generates DHEA after cleavage of the sulfate group. For many years, the physiological significance of 
DHEA remained elusive. However, many studies have now shown that DHEA has significant immune modulatory functions, exhibiting both immune stimulatory and anti-glucocorticoid effects (for review see Hazeldine et al. 2010). DHEA-S increases superoxide generation in primed human neutrophils in a dose-dependent fashion, thereby impacting a key bactericidal mechanism (Radford et al. 2010). In murine models, exogenous DHEA counteracts stress-induced glucocorticoid immunosuppression and increases the resistance of mice to viral and bacterial infections (Ben et al. 1999; Zhang et al. 1999). In murine model systems of aging, DHEA appears to reverse the immunological defects seen as a consequence of aging. In particular, DHEA increases the ability of old mice to resist experimental viral and bacterial disease (Daynes et al. 1993; Kalimi and Regelson 1990; Straub et al. 1998). DHEA administration also restores immune function after thermal and trauma-hemorrhage injury and reduces mortality rates from septic challenge (Knoferl et al. 2003). In addition, DHEA provides protection against several diseases, including diabetes, oncological disorders, autoimmune disease, and chronic inflammatory illness (Kalimi and Regelson 1990). DHEA appears to be a potent regulator of cytokine production supporting the idea that this molecule acts on T cells, which is the lynch pin of the adaptive immune response. However, conflicting results on cytokine production in the presence of DHEA have been reported (see Table 30.1). In vitro studies (Du et al. 2001; Powell and Sonnenfeld 2006) showed that DHEA may be an important factor for increasing TH2 cytokine synthesis, which encourage vigorous antibody production and are commonly associated with antibody responses important for resisting infection, and decreasing TH1 and proinflammatory cytokine production. However, DHEA has shown an opposite effect in vivo in which a TH2 downregulation (or TH1 upregulation) associated with DHEA administration has been found in old or retrovirus-infected mice (Inserra et al. 1998; Zhang et al. 1999; Araghi-Niknam et al. 1997). These discrepancies may reflect differences in assays used to determine DHEA effects on cytokine production or differences in animals used. Additionally, whereas in vitro DHEA is protected from biomodifications, in vivo DHEA administration could lead to rapid clearance from the blood and conversion to other steroids in peripheral tissue, which can affect T cells differently from DHEA. Despite these contradictory data, DHEA seems to be an interesting countermeasure to fight the effects of spaceflight-associated stress on the immune system.

\subsection{Conclusion}

The combination of antioxidants and the pharmacologic, immune-directed action of nucleotides, AHCC and DHEA show various degrees of efficiency to restore immune system alterations. Some of these molecules are able to restore one part of the immune response such as AHCC, which mainly restores innate immunity, while others, like antioxidants, have a more general action on the organism. Searching for efficient countermeasures is a promising area of research that deserves more investigation to counter or restore alterations of the immune system in Space and on Earth. 
Acknowledgments JPF and his team were supported by the French National Space Agency (CNES).

\section{References}

Araghi-Niknam M, Zhang Z, Jiang S et al (1997) Cytokine dysregulation and increased oxidation is prevented by dehydroepiandrosterone in mice infected with murine leukemia retrovirus. Proc Soc Exp Biol Med 216:386-891

Aviles H, Belay T, Fountain K et al (2003) Active hexose correlated compound enhances resistance to Klebsiella pneumoniae infection in mice in the hindlimb-unloading model of spaceflight conditions. J Appl Physiol 95:491-496

Aviles H, Belay T, Vance M et al (2004) Active hexose correlated compound enhances the immune function of mice in the hindlimb-unloading model of spaceflight conditions. J Appl Physiol 97:1437-1444

Aviles H, O’Donnell P, Sun B et al (2006) Active hexose correlated compound (AHCC) enhances resistance to infection in a mouse model of surgical wound infection. Surg Infect (Larchmt) 7:527-535

Aviles H, O'Donnell P, Orshal J et al (2008) Active hexose correlated compound activates immune function to decrease bacterial load in a murine model of intramuscular infection. Am J Surg 195:537-545

Baqai FP, Gridley DS, Slater JM et al (2009) Effects of spaceflight on innate immune function and antioxidant gene expression. J Appl Physiol 106:1935-1942

Bascove M, Touche N, Frippiat JP (2008) Pleurodeles waltl humoral immune response under spaceflight conditions. J Gravit Physiol 15:151-152

Bascove M, Huin-Schohn C, Gueguinou N et al (2009) Spaceflight-associated changes in immunoglobulin VH gene expression in the amphibian Pleurodeles waltl. FASEB J 23:1607-1615

Belay T, Aviles H, Vance M et al (2002) Effects of the hindlimb-unloading model of spaceflight conditions on resistance of mice to infection with Klebsiella pneumoniae. J Allergy Clin Immunol 110:262-268

Ben ND, Padgett DA, Loria RM et al (1999) Androstenediol and dehydroepiandrosterone protect mice against lethal bacterial infections and lipopolysaccharide toxicity. J Med Microbiol 48:425-431

Burikhanov RB, Wakame K, Igarashi Y et al (2000) Suppressive effect of active hexose correlated compound (AHCC) on thymic apoptosis induced by dexamethasone in the rat. Endocr Regul 34:181-188

Cancro MP, Hao Y, Scholz JL et al (2009) B cells and aging: molecules and mechanisms. Trends Immunol 30:313-318

Cogoli A, Tschopp A, Fuchs-Bislin P (1984) Cell sensitivity to gravity. Science 225:228-230

Crucian BE, Stowe RP, Pierson DL, Sams CF (2008) Immune system dysregulation following short- vs long-duration spaceflight. Aviat Space Environ Med 79:835-843

Daynes RA, Araneo BA, Ershler WB et al (1993) Altered regulation of IL-6 production with normal aging: possible linkage to the age-associated decline in dehydroepiandrosterone and its sulfated derivate. J Immunol 150:5219-5230

Du C, Guan Q, Khalil MW et al (2001) Stimulation of TH2 response by high doses of dehydroepiandrosterone in KLH-primed splenocytes. Exp Biol Med 226:1051-1060

Fleming SD, Edelman LS, Chapes SK (1991) Effects of corticosterone and microgravity on inflammatory cell production of superoxide. J Leukoc Biol 50:69-76

Gil A (2002) Modulation of the immune response mediated by dietary nucleotides. Eur J Clin Nutr $56: \mathrm{S} 1-\mathrm{S} 4$

Glaser R, Sheridan J, Malarkey WB et al (2000) Chronic stress modulates the immune response to a pneumococcal pneumonia vaccine. Psychosom Med 62:804-807 
Glaser R, Kiecolt-Glaser JK (2005) Stress-induced immune dysfunction: implications for health. Nat Rev Immunol 5:243-251

Gridley DS, Nelson GA, Peters LL et al (2003) Genetic models in applied physiology: selected contribution: effects of spaceflight on immunity in the C57BL/6 mouse. II. Activation, cytokines, erythrocytes, and platelets. J Appl Physiol 94:2095-2103

Guéguinou N, Huin-Schohn C, Bascove M et al (2009) Could spaceflight-associated immune system weakening preclude the expansion of human presence beyond Earth's orbit? J Leuk Biol 86:1027-1038

Guéguinou N, Huin-Schohn C, Bascove M et al (2010). The immune system under altered gravity conditions. J Gravit Physiol in press

Hales NW, Yamauchi K, Alicea A et al (2002) A countermeasure to ameliorate immune dysfunction in in vitro simulated microgravity environment: role of cellularnucleotide nutrition. In Vitro Cell Dev Biol Anim 38:213-217

Hazeldine J, Arlt W, Lord JM (2010) Dehydroepiandrosterone as a regulator of immune cell function. J Steroid Biochem Mol Biol 120:127-136

Hirose A, Sato E, Fujii H et al (2007) The influence of active hexose correlated compound (AHCC) on cisplatin-evoked chemotherapeutic and side effects in tumor-bearing mice. Toxicol Appl Pharmacol 222:152-158

Holen E, Bjørge OA, Jonsson R (2006) Dietary nucleotides and human immune cells. II. Modulation of PBMC growth and cytokine secretion. Nutr 22:90-96

Inserra P, Zhang Z, Ardestani SK et al (1998) Modulation of cytokine production by dehydroepiandrosterone (DHEA) plus melatonin (MLT) supplementation of old mice. Proc Soc Exp Biol Med 218:76-82

Kalimi M, Regelson M (1990) The biologic role of dehydroepiandrosterone (DHEA). Walter de Gruyter, New York

Kennedy AR, Ware JH, Guan J et al (2004) Selenomethionine protects against adverse biological effects induced by space radiation. Free Radic Biol Med 36:259-266

Kennedy AR, Guan J, Ware JH (2007) Countermeasures against space radiation induced oxidative stress in mice. Radiat Environ Biophys 46:201-203

Knoferl MW, Angele MK, Catania RA et al (2003) Immunostimulatory effects of dehydroepiandrosterone in proestrus female mice after trauma-hemorrhage. J Appl Physiol 95:529-535

Konstantinova IV, Rykova MP, Lesnyak AT et al (1993) Immune changes during long-duration missions. J Leukoc Biol 54:189-201

Kroboth PD, Salek FS, Pittenger AL et al (1999) DHEA and DHEA-S: a review. J Clin Pharmacol 39:327-348

Kulkarni AD, Yamauchi K, Hales NW et al (2002) Nutrition beyond nutrition: plausibility of immunotrophic nutrition for space travel. Clin Nutr 21:231-238

Kulkarni AD, Yamauchi K, Sundaresan A et al (2005) Countermeasure for space flight effects on immune system: nutritional nucleotides. Gravit Space Biol Bull 18:101-102

Maldonado J, Navarro J, Narbona E et al (2001) The influence of dietary nucleotides on humoral and cell immunity in the neonate and lactating infant. Early Hum Dev 65:S69-S74

Matsui Y, Uhara J, Satoi S et al (2002) Improved prognosis of postoperative hepatocellular carcinoma patients when treated with functional foods: a prospective cohort study. J Hepatol 37:78-86

Morey-Holton ER, Globus RK (2002) Hindlimb unloading rodent model: technical aspects. J Appl Physiol 92:1367-1377

Nagafuchi S, Katayanagi T, Nakagawa E et al (1997) Effects of dietary nucleotides on serum antibody and splenic cytokine production in mice. Nutr Res 17:1163-1174

Navarro J, Ruiz-Bravo A, Jiménez-Valera M et al (1996) Modulation of antibody-forming cell and mitogen-driven lymphoproliferative responses by dietary nucleotides in mice. Immunol Lett 53:141-145

Nogusa S, Gerbino J, Ritz BW (2009) Low-dose supplementation with active hexose correlated compound improves the immune response to acute influenza infection in C57BL/6 mice. Nutr Res 29:139-143 
Powell JM, Sonnenfeld G (2006) The effects of dehydroepiandrosterone (DHEA) on in vitro spleen cell proliferation and cytokine production. J Interferon Cytokine Res 26:34-49

Radford DJ, Wang K, McNelis JC et al (2010) Dehdyroepiandrosterone sulfate directly activates protein kinase C-beta to increase human neutrophil superoxide generation. Mol Endocrinol 24:813-821

Rykova MP, Antropova EN, Larina IM et al (2008) Humoral and cellular immunity in cosmonauts after the ISS missions. Acta Astraunautica 63:697-705

Smith SM, Zwart SR (2008) Nutrition issues for space exploration. Acta Astronaut 63:609-613

Stein TP, Leskiw MJ (2000) Oxidant damage during and after spaceflight. Am J Physiol Endocrinol Metab 278:E375-E382

Straub RH, Konecna L, Hrach S et al (1998) Serum dehydroepiandrosterone (DHEA) and DHEA sulfate are negatively correlated with serum interleukin-6 (IL-6), and DHEA inhibits IL-6 secretion from mononuclear cells in man in vitro: possible link between endocrinosenescence and immunosenescence. J Clin Endocrinol Metab 83:2012-2017

Wambi C, Sanzari J, Wan XS et al (2008) Dietary antioxidants protect hematopoietic cells and improve animal survival after total-body irradiation. Radiat Res 169:384-396

Wambi CO, Sanzari JK, Sayers CM et al (2009) Protective effects of dietary antioxidants on proton total-body irradiation-mediated hematopoietic cell and animal survival. Radiat Res 172: $175-186$

Wan XS, Bloch P, Ware JH et al (2005) Detection of oxidative stress induced by low- and highlinear energy transfer radiation in cultured human epithelial cells. Radiat Res 163:364-368

Wang S, Welte T, Fang H et al (2009) Oral administration of active hexose correlated compound enhances host resistance to West Nile encephalitis in mice. J Nutr 139:598-602

Weiskopf D, Weinberger B, Grubeck-Loebenstein B (2009) The aging of the immune system. Transpl Int 22:1041-1050

Yagita A, Maruyama S, Wakasugi S et al (2002) H-2 haplotype-dependent serum IL-12 production in tumor-bearing mice treated with various mycelial extracts. In Vivo 16:49-54

Yamauchi K, Hales NW, Robinson SM et al (2002) Dietary nucleotides prevent decrease in cellular immunity in ground-based microgravity analog. J Appl Physiol 93:161-166

Zhang Z, Araghi-Niknam M, Liang B et al (1999) Prevention of immune dysfunction and vitamin E loss by dehydroepiandrosterone and melatonin supplementation during murine retrovirus infection. Immunology 96:291-297 